\title{
Multilateral Trading Rule in Information and Telecommunications Sector: A Gigantic Leap Toward the Global Information Society"
}

\author{
BYLNG-II CHOI

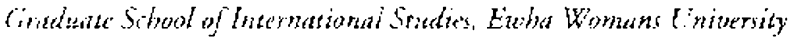

\begin{abstract}
Tho bistonical thading agreements wore made in the early part of 199; at the World Trade Organization (WTO). One is the WTO agreement on bais telecommunications services and the other is the Information Technology Agreement (ITA). With the ITA and the basic telecommunications agrement, the firm ground for aduancing the vision of the Global Information Infrastructure (CII) is now estatblished. This paper revieus the essential elements of the two agreemonts, discusses and analyze's bou they are related to the aduncement of ihe Cill.
\end{abstract}


A s the world marches ino the dawn of a new millennium, it becomes quite clear even wo ordinary poople that che post-industrial suciety is indeed evolving into a sxeiety where information is the essential input of ecomomic activites. "The Third Wave" and "Mega Trend." as dubbed by futurists, are turning into a hard reality due to continuous rechmological advances in the field of information and telecommunications (infocommenications, in the Japarnese parlance). By nature, info-cimmunications technolugy is global, which minns that restrictions irmosed by soverejgn nations prevent commercial potcatial of info-communications technology from being fully realized. In chis regard. it is no surprixe to sec the 13.5 . miniative in pursung the vision of the global information socitry in light of the leading position U.S. herds in this field of info-commonications.

1) 1994, in Buenos Aisce, ly. Vice President Gore called on the nations of the world co join in building the (jobal Information Infraseructure (CiI) - a futuristic digital information superhighway along which all sionts of information, i.e., voice, data and video can be instantly and freely flow treond geographic and policical limitations. In 1995, the Korean govenmont has developed the notion of the Asia-Pacific Information

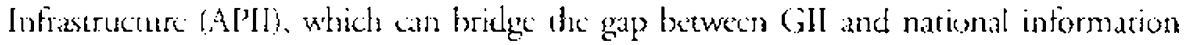

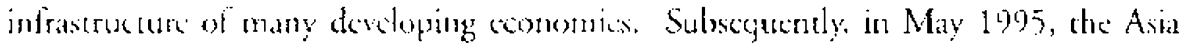
Paxific Konomic Conneration (APEC) Mintsrerial Meeting adopted the principles and Erals sei out in the Seonl Declatation. The Organization for Feonomic Cooperation and Developmen (OECD) has worked on the regulatory and policy frameworks tor the GIl dhroughout 1995, and adopted the guidelines in 1996. Global Information Sociery (CIS), which means a globally interonnected sociey uing the (ill, became an official jargen ol de OECI).

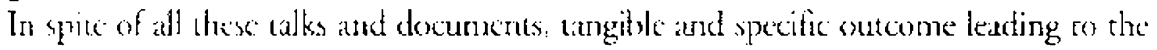
Gill was nor in sight. Many skeprics thought that the GIl was long on thery and short on practice. In the meantime, technokgical and business envimonments have becn coolving at an unprecedented pace. A common approach at a miltilateral arena was in desperate need. The gidotat community stood up to this challenge by establishing a multilateral

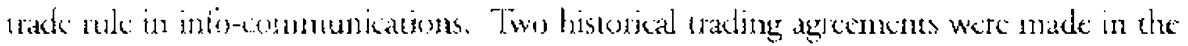
early patt of 199 at the WTO. One is the WTO agrecnent on basic tedecommunica-

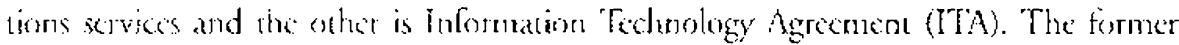
deals with market acess and foreign investment o telcommunications service sector, and the latter addrexices fire-flow of information technology products across national borders. Wirh the IYA and the basic telecommunications agecomenc, the firm ground for advancing the vision of the (jll is now estabistod.

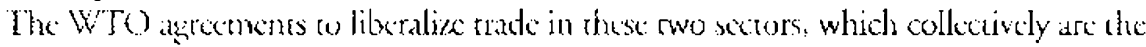

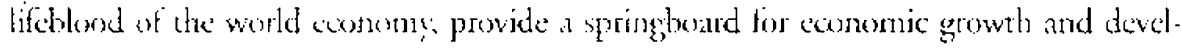
copment in the next contury, In statistical terms, these two accords cover intemational

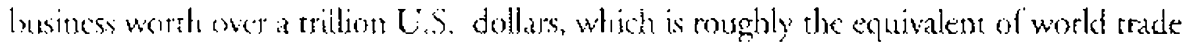
in agricalture, atumohile and textiles put cogesher. The importance of the agreements goes well beyond these numbers. 'The enthusiasn and support for the WrIO negotiattoms on both xutors underscone the recogrition of countries at all levels of development

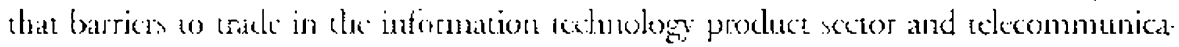


tions service scctor are incomparible with cconomic growth. This paper reviews the esienuial elements of the two agreements, discusses how they are related to the advancemenc of the GIl, and analyes the future challenges ahcad from the perspoctive of developing countries.

\section{INFORMATION TECHNOLOGY AGREEMENT}

\section{Negotiating Process}

The great suceess of the world trading system after World War II is based on the continuous expansion of market access opportunities for trade. In the case of trade in products. the existence of secure and predicrable market access is largely deternined by the use of tariffs. While quosas are outhawed in principle, tariff's are legal in the WTO and are commonly used by governments to protect domestic industries and to raise revenucs. However, tariff meatures are subject to disciplines of non-discrimination-Most Favored Nations (MFN') and national trcatment - and are largely "bound." lo be "bound" means that a tariff level for a particulat product becomes a commitment by a WTO member and cannor be increased withour negotiarion on compensation with its main trading partners.'

Following the establishment of the Ceneral Agreement on Tarifs and Trade (GATT) in 1948, average tarift levels fell progressively and drantatically through a series of eight rounds of trade negotiations; avelage tariff at the border was decteased from around 40 percent in 11) 48 10 bolow five percent afur the Lruguay Round in 1994. The Uruguay Round achieved substantial tariff-cutting, sometimes ro zero, while raising the overall level of bound arifis significantly. Tariff reductions, for the mose part, phased in over five years, will result in a 10 percent aut in developed councries' cariffs on industrial products. from an average of 6.3 percent to 3.8 petcent, and a jump from 20 to 44 percent in the value of imported industrial products that receive duty-free treatment in developed countries. 'The liruguay' Round increased the percentage of bound product lines from 78 10 1) percen for developed counneres, 21 to 73 percern for developing economies and from 73 ro 98 percon for comomies in tansition results which provide a substantially higher degree of market security for tradess and investors.

Recent efforts to literalize trade in information technology products have gained ground as more conncries becurne aware of the vast market potential in this sector. Fxports of information cechnolugy products amounted to more than $\$ 595$ billion in 1995. Trade in this sector is now larger than world exports of agricultural products. Intormation technology industry is currenty che fastest gresving sector. and includes a wide range of items, trom computers and scmi-conducrors to telecommunications equipment and integrated circuits. Broader categories include some of the follewing: compurers, computer parts and computer software; semi-conductors and integared circuits; and relecommunications equipment, including opro-electronic and tadio-based network equipment. 
Six countries and European Union (Ll;) make up the bulk of exports and imports in the information celmology product scetor: Japan, the U.S., EU, Singapore, Korca, Malaysia and Chinese Taipe. Excepe for EU, these are nember economies of the APEC. Hence, the etuthustasm and suppore of the APEC. was the key to the success of the Information. Tethmolugy Agrecment. I.ike any typical major trade negotiations, talks w climinate tarifts on all information technology products by the year 2000 were held throughous 1906 by the (Zuad $\cdots$ Canada, EL', Japan and the L.S. In late September 1996, these counsties expressed hope that by bringing the I'lA to the first WIO Miniserial Conlerence in Singapore in Docember 19!)6, they could oncourage other expreters and importers 10 ntake sinvilar commitments, and climinate all tariffs. The: political momentum was huilding at the APEC. Economic Leaders Meeting in Novembet 1996; AIPC: I eaders gave unqualifed supporc for the TTA. A milestone was reached at the WTO tirse Ministerial Conterence in Singapore in December 1996.

The WTO Ministcral Declaration on Tiade in Intormation Tcchnology Products (ITA) was agreed at the dose of the first WIO) Ministerjal Conference on December 13.

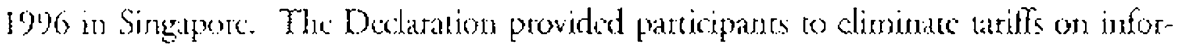

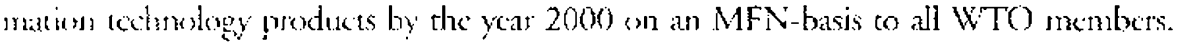
In Singrapore, 29 participants, accouncing lot about 83 percent of trade in information technokgy jroducts, agreed to the ITA. The Declaration, however, provided that implomentation is ontingent on expanding "l'A participation to cover 90 percent of world tsade in Inturmation. Technology (J'T) products by April 1. 1997. Since that cimce nege(iaturs have becon werking to finalize the agrement, and to work with other countries interested in joining the TIA. The ITA participants, who nee in Geneva on March 26. 1997 agred that this crerion had been met: the theshold was finally reached when Malaysia and Thaland agreed to rake parr. Their support and that of Korea, India. Indonesia. Chizese Taipej and Cosa Rica came after trading partners agreed to a longer phase-out of up to the year 2005 for certain products.

\section{Major Contents of the Agreement}

linctet the ITA. whe writf cuts will conce in four cqual installnucnts, beginning July 1997 and continuing on January 1 at each year unril 2000 . Howcver, some countries agred for fascer implementation of tariff cues on eniconductors. They also estahlished Commiece on the Expansion of lrade in Information ' lechnology Products, which will

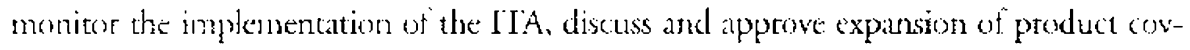

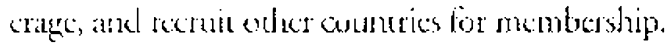

The agrement provides fer the dimination of gariffs on information technology produts by the yat 2000. Coumtres will stage the overwheming mijority of their tariff reducrions a we hy the yar 2000 . In very limited circumstances, cxtended staging of commiements up to the year 2605 was agted ufw for a tew countries. The Agreement also provides for a review of pueduct soverage and a continuing opportunity to pursue mon-taritt newatiace that imelede market aceens for information technology products. 


\section{Parricipants}

There are 2y participants at the Singapore Ministerial Conference Australia, Canada, the 15 mombers of the Eurspcin Communicy, Hong Kong lceland, Indonesia, Japan, Korea. Liechtenstein, Norway, Chinese Taipei, Singapore, Switzerland, Turkey and the L.S. Thirteen addirional countries have come on board since the Singapore Ministerial Conference -. Costa Rica, Czech Republic, Esionia, India, Istael, Macau, Malaysia, New Laland, Romania, Stovak Republic, Thailand, Panana and Poland.

\section{Iariff-Reduction Tine France}

The ITA provides for the staging of tariff reductions in four equal-rate reductions (25 percent reduction in each time):

First reduction: July 1. 1997

Second reduction : January 1, 1998

Third seduction: January 1, 1949)

lourth reduction : Complete climination of duties no later than January 1, 2000

Costa Rica, Indonesia, India, Kotea, Malaysia, Chinese Taiped and Thailand bave been granted thexibilizy in atring their tarisfs on a few products to zero atter the year 2000, but no heyond 2005. IT tariffin in the (uad countries are generally low bur some duties reach as higly as 17 percent. Relacively high tarift's are concertrated in teleconmunications in the IJ.S. and Canada, and in semiconductors in the EU. Many developing country partiejpants apply high tarifts or IT products, including more thin 50 percent in some cases.

\section{Pouduci Coverage}

World trade in I" products is significant - abour $\$ 600$ billion annually, or about i0 percent of world merchandise rade. A total of 202 products are covered by the agreenent and ther belong to the following six main categories:

a) Computers, including conplete compluter systems and laprops as well as compucer components such as Central Procossing Lnits (CPUs), kcyboards, printers, display units (noryians), scanness, hand disk drivers, and power supplies;

b) Telcomsmunications equipment, induding telephone sets, videophones, fax machincs, swirching apparatus, nodems, and pars thereof. 'Telephone handsets, answering mackincs, tadio-broadcasting and celevision transmission and reception ippratus, and pagers;

c) Semiconductors inchuding chips, waters of various sizes and cupacities;

d) Semicondector matnufacturing equipment. including a wide variety of cqupment and escring appararus used an produce semiconducers such as vapor deposition apparatres, spin dryers, etching and stripping;

c) Software contained in diskettes. magnetic tapes, and CD-ROMS;

f) Scientitic instrumetres, including measuring and checking dovices, chromatographs, spectrometers oplical radiation devices and electrophoresis equipment. 
Additionually other main products of interest covered by the I $[\mathrm{A}$ include word processors, alctuators, sash registers, Auromatic Teller Machines (ATM), optical filxt cables, and conn. puter notwork equipmen. The liA does not wover consumer elentronic goods.

\section{Innovation in the Negotiating Approach}

"The liA grew from the concepe of "zero for wero," which was used in the Lruguay Round of multilateral crade megotiations. As a benchmark to reduce aaffe on manufactured produets, it was sugeested that tarifi on a selected group of products la abolished fot all countrics. Nuhough die "aro for zero" approach was considered to be a sensible step in reach-

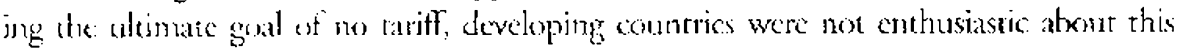
approach mainly duc wo the political implication of dismantling protection given to theit fragile domesia industry. One nay wonder why the "zeto for wero" approath, which did nes work during the Lirugtay Round, hass worked at the I'TA. At least no important reasome may be provided. One is related to the rowely in tealing with the issue of MFN.

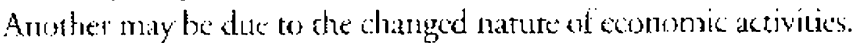

The most fundamkntal minstay of the antrilaterit mading regime is the principle of MFV. L sing the MFN as a negutating loes and as an ohligation of all CAT7 members, the world communicy has achieved a phenomenal growth in work trade, and decpened the integration of thational econonics. However, there hai always been a concern about the free-rider problem associated with MFN. lo urercome the fee-rider problem it has been an crablished negotiating partern at de CATT that in principk, all the countries ate tequested to make a concession on taritt reduction.' Negotiations would consunue'

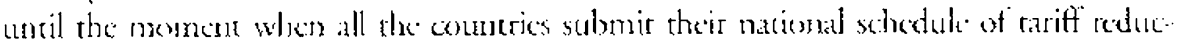

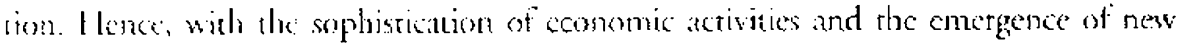
products, multiliteral ariff neegrtarions woukd ake longer

When it comes so the issuc of MFN' the lTA has adopted the concept of critical mass. As long as the critical nas of countries has subnited their tariff reduction schedules, the negrotiatians: would be concluded, and the benefits of the agrenuent would be extended

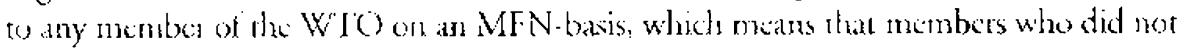

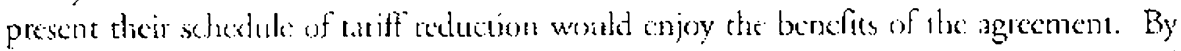
string the atical mass at the yo perenc of the wotd marker, all the negotiators shared the sane necroriating goal. Eqtially important, the concepe of critical mass was not in the cyes of the majus trakling frertens, since the exace configuration of countries did not mates muth: as long as the numerical goal of yo percent was obtained

Then, the nex qulestion lies in the uther ten percent al countrics outside of the cricical mass. In lighe of the gremeth porential of [I' produces and its repercussion on othic cos-

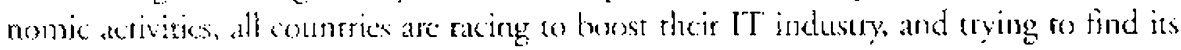
niche and sustain its comperitive codse in the global division of labor. Considering the amount of mones involved in the I"T indurtry, negotators became quite consinced that the cricical mass approach would work. According to their reasoning, the fact that a

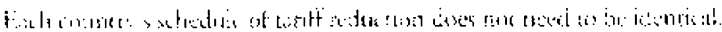


councry is nor a member of the ITA would signal to the international community its lack of political commitmenc to support the growth of the l'f industry, which is believed to be crucial to sustain cconomic growth. Compared with orher countries which joined the ITA, thi councry would be in a disadvantageous posicion in attracting forcign moncy, people, and tcchnolegy. Fron this perspective, negrotiating to reach the critical mass and extending MFN reament to all members of the WTO was an expedient strategy.

\section{Economic Impacts}

From the standpoint of the government of developing countries which levied high tariffs sn IT produch, the [ГA would moan a reduced government revestue and elimination of protective measure for local II industry competing with imported IT products. This is a short-term cost, which would be nfferet and overshadowed by mid-and long-term bene. firs usually in the form of more efficient reorganization of local industry and rallocarion of labor input and capital purstant to market dynamics.

'The staging of tarifi climination will bogin in 1997 with tariffs being climinated by 2000. Such stakging witl keep pace with the bulk of the industrial tariffs agreed in the Unuguay Kound, and will assure that IT industries compete in the global market place on a lewd playing field. Industry expers obsenve thar the usefil commercial life of IT products is about 88 months due to the fast pace of technological development of these prodacts. Experience suggests that those economies that have the lowest tariffs on IT produces hate had the most dynamic I'l sectors. Frat from encoutaging the development of the information industry and its products, tarifts have cocumbered this development, and act as a tax on the comperitiveness and productivity of other industries that rely heavily on IT.

An escential feature of the lTA is that tarifts would be staged to zero, and that governJucus would be legally bound by such commiments. The ITA will provide a stable business onvinanment necessary for long-rem decision-making inyolved in large-scale investments. With ariffs of IT products reduced to zero, cost of moving up the technological ladder is reduced in the mid- and long-term. This will facilitate plugging into, and achicting the vision of the (ill.

\section{BASIC TEI ECOMMUNICATIONS AGREEMENT}

On Hebruaty 15, 1499 , the WTO successfilly concheded nearly thee years of extended negotiations on market access for basic relecommunications services. A total of 71 govemments presented offers by the close of the negotiations, and the commitments of 69 of these governments (comtained in 55 schedukes, taking the 15 member states of the Europann Lnion as onc) are ro be annexed to the Fourth Protocol of the Gencral

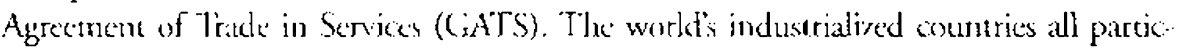
ipated in the agreement. Over 40 developing countrics, large and smatl, from virtually cvery region of the world, also cook part as did six of the Central and Fastern Furopean ecoromies in transition. The markets of the participants accounted for more than 90 
percent of sonet $\$ 600$ billion global telecommunications services market.

\section{Metor Eloments of the Agreement}

The accord on basic elecommunications was conduded under dic (aTS of the WTO. The CATS incorporates munally-agred contractual rights and obligarions, which make the GATS both a code of rules and a forum to negotiarc improved trade opportunities, and to resolve rade disputes. The GATS makes it possible to prevent new distorrions to trade in sorvicos and wo roll hack cxisting barrices, while safeguarding the right to regulate

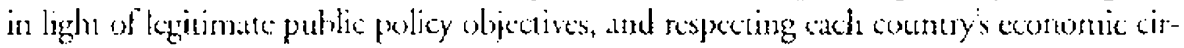
comstances.

The GATS stmuture of rights and othigations tests on three pillats: a framework agreemenr: secroral annexes; and schedules of specifis comminnents. Under the CATS, there is a commitment w progressive literalization, but there is no obligation to give matket access

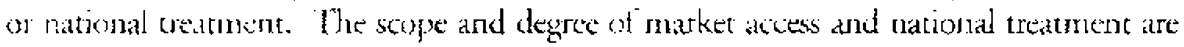
decemined through a serren of megociations, which usesilly proked on the basis of reyuests ark offers atmeng interesed countries. A sisceesful round of muleilateral negotiations will

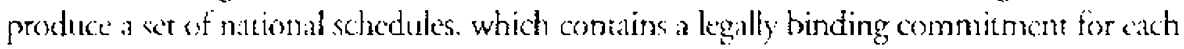
parricipatings memler in mathet acess and national treatment in the negotianed service sector. A member may atuach conditions to hese commitmonts. It may also undertake addicionat commiments which go beyond market access or national treatment.

What bas been negotiated in the accord on basic tekcommunications is adding to the members sctucdules of commiments, which were reached at the end of the Liruguay

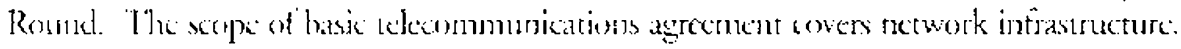

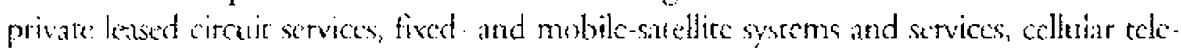
plony. mobile data services paging, and personal communications syatems. The agree ment dexs not anst vitute-dded services: these are aready ifscluded in the schedules of 55 membuts as a resuld of the Lirnguay kound negotiations.

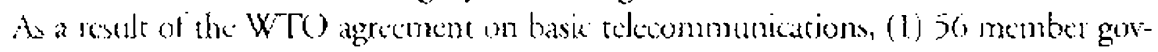

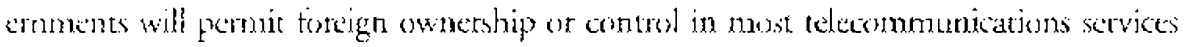

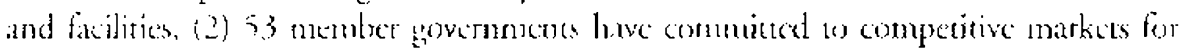

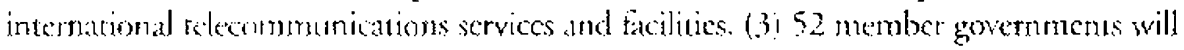
getarante marker itcess for satellice services and facilitios, (4) 63 member governments mernbers will gatantes a pro-compecitive reglatory environment, along the lines of a regulatury reterence paffer negotiated by participants.

White the agreconctic formally ancers inco tisce on Jantary 1, 1998, many mombers

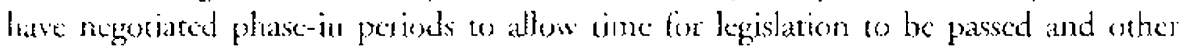
adjustuents of be makte.

Gren that there are no agred definitions of basic relccommunications or even of spe-

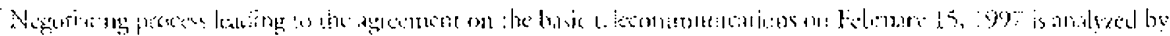

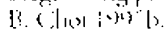

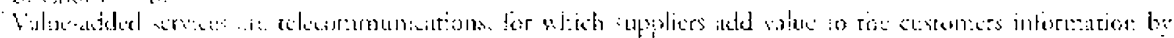

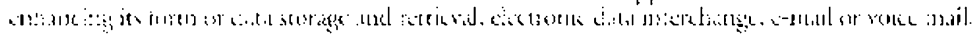


cilic sub-scgments, the hearr of what has been achieved is that whaterer market access is committed to, the tcrms and conditions of participation in a market (as opposed to market entry, whete foreign ownership resurictions apply) will be in contormity with the (AATS rules on tational treatment and MFN treatment. For this teason. the additional commiments on a pro-comperirive regularory environment are probably the most important actievement if the WTO basic telecommunications negotiations."

The principles set out in the tegulatory refetence paper extahlish the Jowest comnon denominator that governmens must filfill in order co ensure a pro-comperitive, transparcut reasomablc and non-discriminatory environment for telecommunications, as competition is introduced. These principles will guide the developnent of laws and regulations by Wro members, while the details and choice of nuans are left to each member to decide.

\section{Economir limparts}

\section{Coverauce}

The agremenc covets over is percent of wotd telecommunications revenue and was negotiated among 70 countries both developed and developing. Before this agreement. only 17 percent of the onp 20 telccommunications markets wete open to forcign service suppliers; now they have access to mearly 100 percent of rhese markets.

The range of services and cohnologies covered by this agrecment is breathaking. Fom aubmarine cables to satcllites, from wide-bund networks to cellular phones, from busines incranet of fixed wireless for rual and underserved regions. the market access opportuntics cover the cotire spectrum of innovalive communications technologies.

\section{Market Access}

With respect to market access, the agreement provides forcign service suppliers market access to locat. long-distance and international services through any means of nework technology, esther on a facilitics basis or through resalc of existing nerwork capacity. On invesment, the agrement also ensures that foreign service suppliers can acquire, cstablish or hold a significan stakc in telecommunications companies around the workd.

International long-distance telephone companics will gain access to serve over 53 markets in Furope. Asia, Larin America and Africa, and obtuin the right ro use their own facilitics and work directly with their customers evergwhere their customess go, providing seamless end-to-end service, not banding off calls to monopoly providers elsewhere. The range of services that cou be provided internationally includes all voice and data services, provided by fixcd on mebile service networks or both. The world's businesses today spend more money on elecommumications than on oil. Less expensive and better

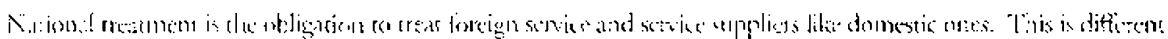

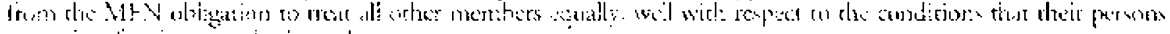

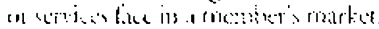

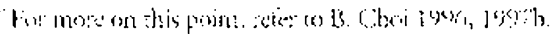


telecommunications services mean that countries active in glotal trade can reduce one of their largest costs of doing business.

An asen latger mumber of markers will be open co compertion for domestic- local and long-distance services. For example, foreign communicatoms companies operaing in Eutope will be ahle to bypass former monopolies and buitd networks directly to, and anong. cuscomers in all member states of the European Lnion. They will have a tair chance to build communications nerwotks that are the key to worldwide economic development. This agreement also provides market access and teftetive interomnection rights for the resale of telecommunications scrvicas. Almost every offer made in these negotiations to provide market acess for facilicio-based comperition also included the opportunity to resell service, and (o) intercomect with coising 1retwotks at reasomable tates, terms and conditions.

\section{Investmunt}

The agrement also ollics inuportant opportunitics for forrign investors and entrepreneurs who are able to acquire, establish or hold a significane stake in telecommunications companies atound ile wotld. These opportunities span into all sectors in basic telecommunications. For cxample, Korean companies will now he free to offer alludar telephonc scrvice is Mexicos strellite sfelivered interner access in Canada, intra-Farope and domestic long distarice in Germany, hand-hold satellite telephony in Cauada, international business networks in Singapore. and video-conferencing in the L'nited Kingdom.

\section{MULTILATERAL TRADING REGIME IN INFO-COMMUNICATIONS AND THF GII: OPPORTUNITIES AND CHALLENGES}

With the ITA and che basic lelecommunicarions agreement, the firm ground for advancing the vision of the Gill is now established. Linderlying principles of tree competition, fait rules and weferive onforcement have prevailed throughour the negotiation process.

The ITA is at the core of the GII. Computer technology along with access to work-

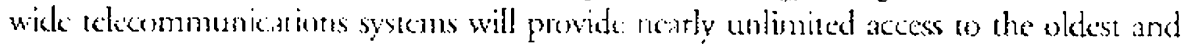
latese developments in the arts and sciences around the world. The information superhighway will open thic minds of stadents w the global environment, and will ensure that the studenes have the necessaty sikilds to compete in the fast-paced wotd. The IT prod. ticts are the intrastracture of businesses. Fncteased compctition will lower prices of these: products whish, in restn, will allow the small- and medium-sized enterprises in other sectors to operate in a more efficiem and cost-clective manner.

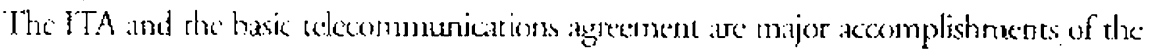
WTO. The significance of the aglecerents is without comparison. At no time in the hisestr of the trading systom lave $s$ maisy sountries united to open up rade in a single sector by eliminating briff and rediccing market access barriers across the board. Agreements of this magnitude traditionally were scured nely as pare of lengty rounds of trade negotiations.

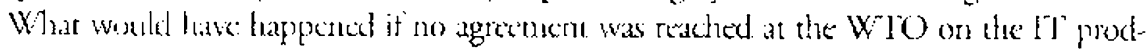


uces and basic telecommunications? Fither a patchwork of bilateral trade agrements or the plurilateral code for a selected few countries would have been a realiscic alternative. In either case, the best possible cnvironment for the growth of the IT and telecommunications sector as well as the growth of the world economy would not be in place since the global nature of rechnology in these sectors could be best utilized under non-discrinninatory market accoss. What was at stake wat the access to the scetors which is estimated to be worth over a trillion U.S. dollars. This is roughly the quivalent of the combined workd trade in agriculture (\$444 billion in 1995), automotrile (\$456 billion) and textiles $(\$ 15.3$ billion).

Fipilly important arc the interests of telecommunicarions uscrs: financial institutions now transmitring $\$ 2.3$ trillion or more electronically every day: companies conducuing busines; educational and rescauch institutions exchanging data and intormation; users of the tapidly expanding Internet; individuals making calls to their fanifics and friconds, or scnding e-mails and atc. Telcommunications is now a vital part of almost all business ransacrions. The telecommunications market would have survived failure in the WTO talks. However, the failure would have had a considerable impact on the costs, prices and efficiency of the sector and other industries, and the investors confidence in comperitive opportuniries.

Beyond the coonomics of making a deal, stability of multilateral trading system was at issue. This was especially the case in basic edecommunications negotiations. In light of the technologioal breakthrough, the ever-inceasing blurring regnlatory boundaries and industry dynamics, the WTO negotiations represented the last opportunity to make a global pact in telecommunications scrvice trade in this century. The successful dcal would ensure regulatory and trade policy of nations consistent with the trade agreement. Market ancess will be granted on non-discriminatory basis and domestic regulations will operate in a transparent, rasonable and impartial manter. Auy membet of une agreeunenr would have recourse to a well-defined WTO dispute settlement procedure, if it bclicves that its benctits under the ayrecmene were nullificd or impaired.

The failure to reach a WTO deal would imply no materiadization of any of these potential benefits. 1nstead, the world would be thrown inte uncercainty and tyranny of unilateralism and bilateralism, where reciptocity becomes the ulcirnate yardscick of market access under the name of the level playing field. History has witnessed that conounes thrive best when a tratsparent predicrable and sable business environment is in place. Simply put, the world community could not afford to lose this unprecedented opportunicy to establish a solid foundation for furthering the walch of the nations, and improving the lives of ordinary people around the world.

It necds to be emphasized, however, that the current arrangements delivered by the II A and the basic telecommunications agreenzents have laid a groundwork for the (ill. lmpressive as the two multilateral agrements may be, nore work needs to be done. More [T-telated products need wo be cowered by the framework of "zero sariff" in the near finure." Incernacional norm on the electronic commerce through Interner needs to be agred upon at the carliese possible time, it the electronic commerce can fully realize its conmercial potencial white minimizing conflicts among nations due to uneven level of sensitiviries to cultural issues. Fossible conflicrs between competition 
policy of countries in the field of info-communications and trade policy are another issue awairing in the wings. Would a competition policy or absence of it in a country have a negative effect on trade, ultimately nullifying or inpairing its market opening commitment? This is an intriguing issue as the basic telecommunications agreement is implemented. The newly established multilareral trading regime on info-communications will provide an internationally-agreed forum for discussing and negotiaring these issutes.

\section{MULTILATERAL TRADING REGIME IN INFO-COMMUNICATIONS AND KOREA}

\section{ITA and Korea}

Korca is ranked as the fifth largest exporter and the eighth largest importer in the I'I products. It exported $\$ 33.22$ billion and imported $\$ 16.47$ billion in the IT products in 1995." The U.S. is Korca's largest trading partner in terms of total trade volume, while Korca runs a high trade deficit will Japan. Korea negotiated for a longer phase-out period to the ycar 2004 for certain products - zeto tariff would be achicved for four items by 2004 and for six items by 2002. Korea agreed for faster implementation of the tariff cuts on semiconductors before the year 2000 along with the L.S. and EU.

The effect of the ITA on Korean trade in the IT products is expected to be modest. The most significant impact of the agreenent is likely to be felt in the areas of Research and Development (R\&-D)), small- and medium-sized companies, industry restructuring, and Korea's iniriative in the APII. The ITA would support the objective of devcloping high technology business in Korea and in the APEC rcgion. Information technology is at the cutring edge of the rechnological revolution. The economies that open their matkets to IT products will exhibit the strongest growrh rates, not only in IT industry but in other industrics which rely on those produces and services. A strong and vibrant small- and medium-sized companies is important for Korea's sustained economic. growth. And the ITA supports the development of small- and medium-sized companies. While the early stage of development of IT industries occurred in large multinational corporations, accelerated growth in IT products has occurred in small- and medium-sized enterprises.

The ITA incorporates the principal objective of trade and investment liberalization of the APEC. By agreeing to zero tariffs by 2000 , the ITA would comply with the basic objective of the Bogor Leaders' Declaration-free and open trade and investment prior to the 2010/2020 ime trame. Al'EC's suppors for the IT'A ckarty demonstrates the seriousness with which $A J F$ F, is committed or free and open trade, especially in products areas where APEC economies are already competitive, and are critical for further APFC development. 
There may be cossespecially for the less developed APEC economies. These costs are higher in the near-term. However, in the medium- and long-terms, the tenefits are significant. The ITA is a "witt-win" proposition for APEC conomics, not just because of the benefics to the IT producers, hut most invporrantly, to all the companies, including small- and medium-sized enterprises that rely heavily on a modern and compctirive IT infrastructure. For this reason, APEC economies actively took part in the negotiations. And in is a living testimony that Chinese Tajpei. which is not a WTO member, made a kegally binding commitmont.

\section{Basic Telecommunications Agreement and Korea}

Through a series of market restructuring initiatives, the Korean government has transformed the basic telecommunsication services from a monopoly to a comperitive market, and the basic tckcommunications service providers are beginning to feel the heat of competition. With the latest licensing decision for the nation-wide second local telephone sersice provider and the third long distance telcphone service provider, it appeats that there would not be much room for futuse marker entry on facility-based compctition.

It this regard, the Korean government's commiunent to the WTO basic telecommetnications agreement is assessed to be modest. Foreign investment in the facility-based operarion will be alkwed up to 33 percent on lanuary 1, 1998 and will be increased up to 49 percert on January 1,2001. There are several teasons behind this level of phase-in commitmonr, including the "fear of forcign control." "no more market opening than other developed countries" and "the lesser the opening the beter for Korea." Most of these ideas ate cither ill-founded misperceptions or misguided logic which gives advantage to domestic incumbents."

Increased market access in basic celecommunications marker will lead to a creation of more jobs-- not only in communications companies but also in the high-rech equipment market, and in the wide range of industries such as software, information services, and electronic puhlishing. 'The agreement will also save billions of dollars for consumers, houstholds as well as comparis.

The basic retecommunicarions agrecment will be instrumental to build the Cilobat Intiormation Highway. It is the perfoc complement to the ITA. The Korcan manufactercrs of relecommunications equipment are compering with the world-dass companies in the domestic and global narkets alike. The basic telecommunicarions agreement will boost demand for tclecommunications equipmont, which will in turn provide incentive for the Korcan companies to be more creative and innovative in $\mathrm{R} \& \mathrm{D}$ and aggressive and consumer-fiendly in narketing. Pro-comperitive terms of the agteenent would firther promote compcition among the manufacturess for the best possible products for consumers.

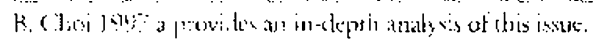




\section{CONCLUSION}

The mululuateral trading system is an attempt by govetnments to provide investons, employees and consumers with a business environment which encourages trade and invertment, and job creacion. It also provides more choices and lower prices in the market place. Through the right kind of trade agteements, more jobs and greater prosperity can be created at home while other nations also prosper and develop. It has now become cliché that information technology and telcconmunications industry is poised to lead the growth of the world economy it the forthcoming centuy in much the same way the automorive industry spurred tremendous industrial growth in the twentiech century. History has observed that stalle and predictable ccononic envitonment holds the key to prosperity for all. The ITA and basic telecommunications agreement recently made at the WTO successfully secured such an environment. The cwo accords meant lower prices for consumers and fewer barriers against the spread of technolugy, which are crucial to the development of all countries in the world.

The ITA and basic telecommunications agteement togecher hold the potential to unlock enormous gains in development and growth which would benefit all countrics, dcycloped and developing alike." Knowledge and information are the most essential raw material in the global cconomy, and IT products and telecommunications services are the essential conduit for their delivery. By making such products and services more affordable and accessible, the world will move one step closer to the vision of "a telephone in cvery village in the world," and the vision of the gobal information sociery. A solid foundation has been established for a global economic infrastructure nceded for trade expansion as the wotld moves on to the next ecnenry. Now, the ball is thrown to each and every economic players in the world. Whether or not they will reap gains, and how much benefiss to be realized is up to them.

\section{REFERENCES}

Choi, Byung-il. 1994. "Dance of Hemisphere-Vision and Reality of the GII from a Developing Country Verspective." Paper presented to the KISLI-CSIS Workshop on Economic and Polic; lssues on Lifornation lnfrastructure, Seoul, Korea, October 13.

Choi Byung-il. 1996. "U.S. Strategy in Multilatcral Trade Negotiations on Telccommunications Service: Its Fvolution and Ffficjency." loumal of Negatiations Studies 2(2), 17-37.

Choi: Byung-it. 1997a. "Political Economy of l'decommunications Market Opening in Kored: Interplay of Domesric and Foreign [nterest." Global Economic Review 2, 26, 75-91.

Choi, Byung-il. 1997b. "The Shaping of the WTO Agreement on the Basic Teleconmunications: Negotiations Perspecrives." Joumal of Negotiations Studies 3(1), 17-56.

Genctal Agreement on Tariffs and Trade (GATT). 1994. Article XXVIII. Uruguay.

Ruggiere, Renato. 1997. "Implementing the WTO Singapore Declaration in 1997 and beyond." Address to APEC Trade Ministers, Montreal, May 10.

WrO. 1996. "Ministerial Declatation on Trade in Information T'cchnology Products." Singapore, Decumber 13.

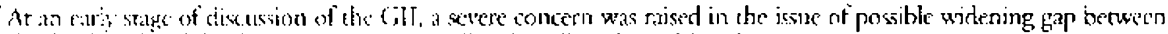

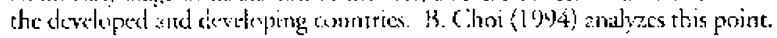

